\title{
Distance Learners' Needs on Interactivity in SMS-based Learning System
}

\author{
Issham Ismail $^{1} \&$ Siti Norbaya Azizan ${ }^{1}$ \\ ${ }^{1}$ School of Distance Education, Universiti Sains Malaysia, Penang, Malaysia \\ Correspondence: Siti Norbaya Azizan, School of Distance Education, Universiti Sains Malaysia, 11800 USM, \\ Penang, Malaysia. Tel: 60-4-653-5439. E-mail: sitinorbaya49@gmail.com
}

Received: March 6, 2012 Accepted: May 24, 2012 Online Published: August 17, 2012

doi:10.5539/ass.v8n11p119

URL: http://dx.doi.org/10.5539/ass.v8n11p119

The research is financed by Universiti Sains Malaysia under the RU Grant.

\begin{abstract}
The literature points to the rise of mobile learning (m-learning) adoption in some higher education institutions in Malaysia. However, the designs of m-learning system in each institution are diverse and may not be carefully designed up to learners' expectation. Needs on interactivity is one aspect to be considered. This study examined the extent to which interactivity is viewed as a key element in designing an SMS-based m-learning system from the perspectives of distance learners. A purposive sample of 61 responses from distance learners from Universiti Sains Malaysia (USM) was analyzed. The results attested that in general, interactivity was viewed as important in their learning process. Specifically, interaction between students and lecturer was mostly preferred by the students, not only for learning communication, but also as a support to the SMS (Short Message Service)-based learning system. Findings in this study are of interest to distance educators and course designers interested in exploring the interactive elements of SMS-based learning applications.
\end{abstract}

Keywords: distance education, distance learners, mobile learning, M-learning, SMS-based learning, interactivity

\section{Introduction}

In reality, distance learners have a variety of needs and characteristics. Reliance on the provided learning system alone does not appear to be the best path for distance learners at present. Within Malaysian context, studies have shown that majority of distance learners are still having low level of learner autonomy ( $\mathrm{Ng}$ and Confessore, 2011; Subramaniam, 2008). As educational technology and learners' behavior keep evolving and proliferating, there is a need for learning institutions to reevaluate their approaches to pedagogy. Regardless of the medium, distance learning courses have common characteristics, and likewise similar problems. One of the major problems is the sense of isolation among distance learners due to the lack of face-to-face contact with instructors and peers. By geographical nature, distance learners have lack opportunities for any form of interactivity due to the physical absence of the teaching and learning environment. Interactivity, regardless of any form, is at the very heart of any distance learning courses. Through interactivity, learning at distant can take place in active engagement form, and subsequently promote learner-centered teaching-learning approach. Despite the needs, not all forms of interactivity are equally valued by the learners as effective. Thus, in designing a learning system for distance learners, interactivity is one of the key elements to be considered and deeply analyzed.

Mobile learning or m-learning is one example of a learning system that is currently growing in invisibility and significance in distance education courses in Malaysia. With the ubiquitous quality of mobile devices, m-learning is mostly considered as a flexible and convenient mode of learning for distance learners to learn at anytime and anywhere at affordable costs. However, in trying to bridge the transactional distance faced by the learners, much more efforts need to be done to minimize the sense of isolation and alienation among the distance learners. M-learning is a relatively immature in most universities in Malaysia in terms of both its technologies and pedagogies. Thus, unfamiliarity with the m-learning technologies may cause the learners to feel isolated since there are less opportunity for interaction and communication with fellow learners and instructors in distance learning environment (Lim et al., 2011). Nevertheless, an m-learning system that is designed by 
utilizing the simplest mobile technology, the Short Message Service, SMS might appear to be a potential solution in bridging the digital gap in Malaysian distance education programs. This is due to the fact that SMS usage in Malaysia is increasing from years to years, specifically, from $31.7 \%$ in year 2004 to $50.7 \%$ in year 2008 (MCMC, 2008).

In line with this need, this paper seeks to clarify the following research questions: "Is interactivity required in an SMS-based learning system designed for distance learners?", "Which type of interaction is considered as the most important by these distance learners?" and "What learning applications are preferred by the distance learners to enhance their interactivity in SMS-based learning?". The rationale to conduct a study into the learners' needs of interactivity in an SMS-based learning system was to identify and understand the specific key elements in designing an interactive SMS-based learning system that is effective in completing current modes of teaching and learning, whilst acknowledging the importance of interactivity in distance learning environment. Subsequently, this paper outlines the possible design criteria of an SMS-based learning system that is useful in promoting interactivity as preferred by distance learners in this study.

\section{M-Learning for Distance Learners}

Nowadays, technology has played a key role in changing the pedagogical approach in distance learning environment. Current trend witnessed in the field of distance education throughout the world is the utilization of mobile device as a boon to support the teaching and learning process. This educational use of mobile device, be it wireless, portable or mobile, is called as mobile learning, or usually termed as m-learning. Through the mobile technologies, m-learning allows anyone to access information from anywhere at any time. This ubiquitous quality of m-learning provides many possible benefits, especially to the distance learners due to their geographical limitation to the learning elements. Earlier studies have shown that m-learning has potentials to increase students' interactivity in learning (Koole et al., 2010; Kumar et. al, 2011), offers more flexibility and wider access to education, as well as enhances collaborative, co-operative and active learning environment (Zawacki-Richter et al., 2009). While proposing the framework of the Mobile Support Synergistic Learning, Lin et al.(2008) suggested that, through strengthen synergistic relationships gained from the system, it allows learners to utilize the space for choosing, aggregating, transforming and delivering their own knowledge. After all, with the convenience and flexibility it offers, m-learning is referred as the future of distance education (Lin et al., 2008).

M-learning is also a relatively new instructional design strategy that is gaining momentum in Asia. Motlik (2008) reported the potentials of Asian distance education to be global leaders in developing the educational uses of mobile phone. Compared to web-based learning, distance learners and instructors in Asia and Africa were reported to be more familiar with mobile phone since the technology is widespread and easy to use. Moreover, SMS-based m-learning has proved to be cost-effective and efficient for delivering the distance learning contents (Motlik, 2008). Yousuf (2007) conducted a study involving distance learners from Allama Iqbal Open University, Pakistan to measure the students' attitude and perceptions towards the importance of m-learning in their studies. It was found that m-learning is helpful in facilitating their learning, which is by enhancing their communications tutors, supporting staffs and among each other. The study also concluded the potential of mobile technologies for the future of learning in developing countries. Within Malaysian distance learning context, studies have shown that there is also a clearly great promise for the use of mobile devices in education. In a study by Ismail et al. (2010), it was found that majority of respondents were satisfied with the use of m-learning in their distance learning program. Furthermore, the respondents also agreed that m-learning is helpful in assisting them to learn distantly. Rosli et al. (2010) and Abas et al. (2009) carried similar studies involving distance learners from two public universities in Malaysia. The two studies also supported the positive adoption of m-learning among distance learners in Malaysia.

In addition to the benefits, there are also a number of challenges identified in the literature. A study by Koole et al. (2010) reported that, even though the respondents from Canadian University interacted more in the mobile pilot than in Moodle, majority did not feel that mobile access is helpful in increasing their motivation to interact, or their sense of connectedness. Qualitatively however, they were reported to value the benefits of mobile devices for real-time communication with lecturers and other learners. Corbeil and Valdez-Corbeil (2007) identified that the distance learners are ready for communication and recreation activities through mobile technologies. However, they might not be ready for the integration of mobile technologies with their teaching and learning activities. Chinnery (2006) also highlighted several limitations of mobile devices as teaching-learning tools, such as small screen size, limited message lengths, one-finger data entry, limited power and limited audiovisual quality. There are some other drawbacks of m-learning which could potentially minimize the interactivity of learners: limited nonverbal communication, lack of cultural context and limited social 
interaction (Chinnery, 2006).

The value of interactivity in distance learning context should not be taken lightly. King and Doerfert (2004) highlighted that, "one of the most important instructional elements of contemporary distance education is interaction. Moreover, researchers have indicated that most distance learners feel more satisfied with m-learning applications that offers more interactivity (Motiwalla, 2007; Yousuf, 2007; Shen et al., 2008).As has been suggested by Wang et al. (2009), if mobile learning is viewed as a device for promoting interactivity, it might be useful to elicit active participation from the students, and thus help them being engaged in the learning process. In fact, it is the lack of chances for learners to interact in the synchronous m-learning activities that motivated Huang et al. (2008) to develop a context-awareness synchronous learning system. It was found by the researchers that, the system is able to enhance the learners' feedback mechanism, and thus implement the enhanced model for achieving mobile interaction in a synchronous learning environment (Huang et al., 2008).

Most of existing research has been carried out for verifying the needs of effective interactions in distance learning environment. Unfortunately, so far few scholars have applied to study what are the elements of the so-called effective interaction that can be implemented to design a usable m-learning system from the perspectives of the learners themselves. Given the growing awareness on the needs of interactivity in distance learning environment, it is important to look at interactivity as a possible design tool to develop an effective SMS-based m-learning system for the distance learners.

\section{Methods}

The study was quantitative in nature and the population was comprised of distance learners who undertook management courses in academic year 2011/2012 from USM. The questionnaires were distributed to 70 distance learners who enrolled the Business Communication subjects during their video conferencing session in USM. Out of 70 questionnaires being distributed, 61 were returned, providing an 87.14 percent return rate.

Instrument used to collect data for this study was Preferences in SMS-based M-Learning System Questionnaire, develop by the researchers. It consisted of six scales and 90 items, whereby the scale on preferences in $\mathrm{m}$-learning methodologies was developed based on the strategies and methodologies in m-learning as proposed by Zawacki-Richter et al. (2009). The scales of preferences in m-learning system had five possible responses that utilized Likert-type scale, ranging from strongly disagree (1) to strongly agree (5). All questions were closed-ended type. Pilot test was performed to 30 undergraduate students to verify the reliability of the instruments which was then reviewed by two field experts to confirm its validity. The Cronbach's alpha value for items on interactivity was found to be 0.867 , which exceeded the conventional minimum value of 0.7 (Nunnaly, 1978). Thus, the measurement was deemed to be reliable.

The statistical analysis software, PASW 17.0 was used to analyze the data in the study descriptively through mean, standard deviation, frequency and percentage analyses.

\section{Results and Discussions}

\subsection{Demographics of the Sample}

The demographics information of sample from this study is given in Table 1. From a total of 61 respondents, 72.1 percent were female. A majority of the students (73.8\%) were in the range of 20 to 30 years of age, while other 26.2 percent were between 31 to 40 years old. In terms of ethnicity, most of the respondents $(81.7 \%)$ were Malay, followed by Chinese (13.3\%), Indian (3.3\%) and other ethnics (1.7\%). In terms of academic profiles, the survey also showed that majority of respondents $(88.5 \%)$ were studying the distance learning course in their first year of that semester. This explains why most of the respondents $(91.2 \%)$ did not have their CGPA yet for the undertaken subject. 
Table 1. Demographic profiles

\begin{tabular}{|c|c|c|}
\hline & Frequency & Percentage (\%) \\
\hline \multicolumn{3}{|l|}{ Gender } \\
\hline Male & 17 & 27.9 \\
\hline Female & 44 & 72.1 \\
\hline \multicolumn{3}{|l|}{ Age (year) } \\
\hline 20 to 30 & 45 & 73.8 \\
\hline 31 to 40 & 16 & 26.2 \\
\hline \multicolumn{3}{|l|}{ Ethnic } \\
\hline Malay & 49 & 81.7 \\
\hline Chinese & 8 & 13.3 \\
\hline Indian & 2 & 3.3 \\
\hline Others & 1 & 1.7 \\
\hline \multicolumn{3}{|l|}{ Marital } \\
\hline Single & 32 & 52.5 \\
\hline Married & 29 & 47.5 \\
\hline \multicolumn{3}{|l|}{ Year of Study } \\
\hline Year 1 & 54 & 88.5 \\
\hline Year 2 & 3 & 4.9 \\
\hline Year 4 & 4 & 6.6 \\
\hline \multicolumn{3}{|l|}{ Current CGPA } \\
\hline Below 2.00 & 1 & 1.8 \\
\hline 2.00 to 2.49 & 2 & 3.5 \\
\hline 2.50 to 2.99 & 1 & 1.8 \\
\hline 3.00 to 3.49 & 1 & 1.8 \\
\hline No CGPA yet & 52 & 91.2 \\
\hline
\end{tabular}

Demographic profiles of respondents include the data of gender, age, ethnicity, marital, year of study and current CGPA.

\subsection{Characteristics of Mobile Phone Usage}

As can be noted from Table 2, finding from this study indicated a positive insight regarding mobile phone ownership among the respondents, where it was reported that $65.6 \%$ of total respondents owned one mobile phone, while the rest $(34.4 \%)$ have more than one mobile phone. In other way, it can be said that $100 \%$ of respondents owned at least one mobile phone. Thus, it can be safely inferred that mobile phone could be the best device to be used as an m-learning tool for distance learners in this study since the respondents were well-familiar with the device, which also a necessity in their daily life. This result is in agreement with Armatas et al. (2005) who reported that, the high level of mobile phone penetration in Australia makes the devices ideal targets for mobile learning applications. In addition, students who are already familiar with mobile devices will find ways to integrate the usage with learning (Corbeil and Valdes-Corbeil (2007). Thus, the ownership and familiarity with mobile devices are some of major key roles that can guarantee a successful m-learning delivery. 
Table 2. Usage of mobile phone

\begin{tabular}{|c|c|c|}
\hline Items & Answer & Responses (n, \%) \\
\hline \multirow{2}{*}{ Amount of mobile phone owned } & One only & $40,65.6$ \\
\hline & More than one & $21,34.4$ \\
\hline \multirow{5}{*}{ Brand of main mobile phone } & Nokia & $33,55.0$ \\
\hline & Sony Ericsson & $15,25.0$ \\
\hline & Motorola & $1,1.7$ \\
\hline & Samsung & $6,10.0$ \\
\hline & Others & $5,8.3$ \\
\hline \multirow{4}{*}{ Service provider of main mobile phone } & Celcom & $14,23.3$ \\
\hline & Digi & $7,11.7$ \\
\hline & Maxis & $38,63.3$ \\
\hline & Others & $1,1.7$ \\
\hline \multirow{2}{*}{ Types of service for main mobile phone } & Prepaid & $37,61.7$ \\
\hline & Postpaid & $23,38.3$ \\
\hline \multirow{7}{*}{ Most frequently used mobile phone application } & Sending SMS & $30,53.6$ \\
\hline & Making calls & $24,42.9$ \\
\hline & Surfing internet & $1,1.8$ \\
\hline & Playing games & $1,1.8$ \\
\hline & Capturing pictures & 0,0 \\
\hline & Listening to music & 0,0 \\
\hline & Others & 0,0 \\
\hline \multirow{4}{*}{ Language mostly used to write SMS } & Malay & $42,68.9$ \\
\hline & Mandarin & $1,1.6$ \\
\hline & English & $11,18.0$ \\
\hline & Mixed language & $7,11.5$ \\
\hline \multirow{5}{*}{ Average number of SMS sent daily } & 0 to 5 & $15,24.6$ \\
\hline & 6 to 10 & $16,26.2$ \\
\hline & 11 to 15 & $11,18.0$ \\
\hline & 16 to 20 & $5,8.2$ \\
\hline & More than 20 & $14,23.0$ \\
\hline
\end{tabular}

Respondents' mobile phone usage statistics include the data on amount owned, brand, service provider, most frequently used application, language used, and average SMS sent daily

Table 2 also reported that, more than half of total respondents (55.0\%) used Nokia mobile phones, followed by Sony Ericsson (25.0\%), Samsung (10\%), and Motorola (1.7\%). The distribution of service providers indicates that Maxis outnumbered other providers by 63.3\% (Celcom: 23.3\%, Digi: 11.7\%, others: $1.7 \%$ ). As for service plan, it is interesting to note that prepaid seemed to be mostly preferred, where $61.7 \%$ of total respondents were using the plan for their main mobile phones. Even though the respondents are distance learners who most probably are earning own incomes, they were not keened toward having postpaid plan for their main mobile phone. 
The data also indicated that majority of respondents use mobile phones more for sending Short Message Service, SMS $(53.6 \%)$ than for making calls $(42.9 \%)$, surfing internet $(1.8 \%)$ and playing games $(1.8 \%)$. None were reported to use their mobile phones more for other applications such as capturing pictures, listening to music and others. Studies among Malaysian student populations reported on their favoritism on using SMS as compared to other mobile phone application (Zulkefly and Baharudin, 2009; Yuen et al., 2008; Hui and Hock, 2005). Hence, this result added to the literature that signals the potential of adopting SMS-based m-learning application as an effective tool to support distance learning courses in Malaysia (Safie, 2005; Ramli et al., 2010). Despite being the most frequently used mobile phone application, SMS application did not appear to be heavily used by the respondents. The finding reported that $50.8 \%$ of total respondents agreed that they send not more than 10 SMS only per day. Nevertheless, some respondents $(23.0 \%)$ appeared to be avid SMS users since they send more than 20 SMS per day. However, in general, it can be implied from this finding that the respondents' frequency of sending SMS was on daily basis. The finding is concurrent with finding by Zulkefly and Baharudin (2009) who reported that $97.7 \%$ of the students send SMS every day.

$68.9 \%$ of total respondents used Malay language to write SMS, comparing to English (18.0\%). This result might be explained by the demographic factor, since majority of respondents were Malay. Furthermore, Malay is the national language of Malaysia. However, $11.5 \%$ of total respondents preferred to use mixed language in writing SMS.

\subsection{Needs of Interactivity in M-Learning System}

Results pertaining to respondents' needs of interactivity in m-learning were described descriptively in Table 3. In general, majority of respondents agreed on the needs of interactivity in m-learning system to support their distance learning process (mean $=3.849$ ). Specifically, the results indicated that, the highest preferences of interactivity in m-learning among the respondents is to communicate with their lecturers (mean $=4.36$ ). It is followed by the respondents' needs to share m-learning resources $($ mean $=4.10)$ and collaborate among each other (mean $=4.09$ ). Most importantly, most of the distance learners agreed that the m-learning system should be interactive (mean $=4.07)$, whereby the students can also interact with the system $($ mean $=3.97)$.

Table 3. The needs of interactivity in SMS-based learning system

\begin{tabular}{|c|c|c|c|c|c|c|c|}
\hline \multirow{2}{*}{$\begin{array}{c}\text { Items } \\
(\text { Cronbach's alpha }=0.867, \text { mean }=3.849)\end{array}$} & \multicolumn{5}{|c|}{ Percentages of Agreement } & \multirow[b]{2}{*}{ Mean $^{\mathrm{a}}$} & \multirow[b]{2}{*}{ SD } \\
\hline & 5 & 4 & 3 & 2 & 1 & & \\
\hline $\begin{array}{l}\text { I understand better when the learning system works in } \\
\text { question-and answer way }\end{array}$ & 32.8 & 36.2 & 20.7 & 8.6 & 1.7 & 3.90 & 1.021 \\
\hline It's hard for me to learn when I do not participate actively & 10.3 & 36.2 & 32.8 & 12.1 & 8.6 & 3.28 & 1.089 \\
\hline $\begin{array}{l}\text { The system should give feedbacks regarding work that } \\
\text { I've done }\end{array}$ & 22.4 & 36.2 & 37.9 & 3.4 & 0 & 3.78 & 0.839 \\
\hline I prefer a two-way method that always assess my work & 25.9 & 37.9 & 32.8 & 3.4 & 0 & 3.86 & 0.847 \\
\hline $\begin{array}{l}\text { The system should allow me to share the resources with } \\
\text { others }\end{array}$ & 36.2 & 43.1 & 17.2 & 1.7 & 1.7 & 4.10 & 0.872 \\
\hline $\begin{array}{l}\text { The system should allow students to collaborate with } \\
\text { each others }\end{array}$ & 35.1 & 43.9 & 17.5 & 1.8 & 1.8 & 4.09 & 0.872 \\
\hline $\begin{array}{l}\text { The system should allow students to communicate with } \\
\text { lecturers }\end{array}$ & 56.9 & 25.9 & 15.5 & 0 & 1.7 & 4.36 & 0.873 \\
\hline I should be able to interact with the learning system & 36.2 & 32.8 & 25.9 & 1.7 & 3.4 & 3.97 & 1.008 \\
\hline The learning system should be interactive & 42.1 & 28.1 & 26.3 & 1.8 & 1.8 & 4.07 & 0.961 \\
\hline
\end{tabular}
(1)

\section{Respondents' needs on interactivity include the interaction with the system, lecturers and peers}

With regards to types of interaction, the aforementioned findings indicated that the student-to-lecturer interaction was mostly preferred by the distance learners in this study. Likewise, the respondents also considered student-to-student and student-to-system interactions as important to them. In the light of respondents' feedbacks, the design elements of m-learning system may need to include the intervention of communicative elements between students to their lecturer, students to students and students to the system. Likewise, these interactions 
might also be useful to support the learning process among the distance learners, as well as to help them adapting to the m-learning system being introduced to them. These results are concurrent with findings by Brown (2003) who reported the models of m-learning via mobile phone for the case of Africa. Communication and interactions with educational institutions, peer learners and study groups were among of the factors being highlighted in both models. Moura and Carvalho (2010) shared their experiences in conducting experiment on using SMS for teaching and learning languages. It was highlighted in the study that mobile technologies are helpful in enabling interaction outside and inside classroom.

\subsection{Preferences in Interactive M-Learning Applications}

In studying the distance learners' needs on interactivity, it is also equally important for researchers to study what types of interactive elements that can be designed as m-learning applications to suit the learners' needs on interactivity. Data in Table 4 provides an overview of the preferred interactive m-learning applications. The highest mean score of 3.87 suggested that query application was mostly preferred by the respondents as an interactive m-learning application, followed by query auto-reply (mean $=3.69)$ and answers to query (mean = 3.57). Overall, these findings suggested that the respondents need an interactive m-learning system that allows them to not only ask questions by their demand (query), but also provide answers instantly to their questions (query auto-reply system). The finding related to the respondents' needs in m-learning system, in particular the query application, is consistent with the study by Corbeil and Valdes-Corbeil (2007). In their study, students were reported to benefit more from the m-learning system if the system enables them to receive immediate responses regarding their individual queries from the faculty at anywhere they are.

Table 4. Preferences in interactive SMS-based learning applications

\begin{tabular}{lcccccccc}
\hline \multicolumn{1}{c}{ Items } & \multicolumn{7}{c}{ Percentages of Agreement } & \\
& 5 & 4 & 3 & 2 & 1 & Mean $^{\mathrm{a}}$ & $\mathrm{SD}$ \\
Multiple-choices quiz & 26.2 & 23.0 & 26.2 & 16.4 & 8.2 & 3.43 & 1.271 \\
Quiz marks & 26.2 & 29.5 & 36.1 & 6.6 & 1.6 & 3.72 & 0.985 \\
Query & 27.9 & 39.3 & 23.0 & 4.9 & 4.9 & 3.80 & 1.062 \\
Answers to query & 21.3 & 34.4 & 29.5 & 9.8 & 4.9 & 3.57 & 1.087 \\
Query auto-reply system & 21.3 & 37.7 & 31.1 & 8.2 & 1.6 & 3.69 & 0.958 \\
Discussion via forum & 10.0 & 23.3 & 38.3 & 13.3 & 15.0 & 3.00 & 1.179 \\
Discussion threads & 16.7 & 30.0 & 36.7 & 6.7 & 10.0 & 3.37 & 1.149 \\
athe means are determined by using a five-point Likert scale rating from strongly agree (5) to strongly disagree (1)
\end{tabular}

Statistics described respondents' preferences in two-way SMS-based learning applications

Other than query, the respondents from this study also preferred to receive their quiz marks through the m-learning system (mean = 3.72). In other words, if the system is to include quiz-like applications, the distance learners in this study need it to be more interactive, which is by providing feedbacks regarding their quiz marks. This finding is supported by Randall et al. (2002) who also highlighted the needs on instant interactivity that works like a live event for students to learn through SMS-based learning. Likewise, Randall et al. (2002) also suggested that the students can receive more rapid feedbacks regarding their work through SMS-based learning applications such as interactive tutorials, exam results, answering multiple-choices questions and real-time quizzes.

Conclusively, this study suggested that, an m-learning system should be designed in such a way so that it will be able to support two-way communications between the distance learners with both lecturers and the system.

\subsection{Preferences in Communicating with M-Learning Supports}

This study also reported the respondents' preferences in communicating with the m-learning supports. Table 5 reported that, the three most preferred m-learning supports by the respondents were portal (mean $=4.20)$, lecturer $($ mean $=4.19)$ and technical staffs $($ mean $=4.05)$. Due to the fact that the respondents preferred to interact with their lecturer and the m-learning system, it is clearly seen that the distance learners need supports from the system through portal and their own lecturer. This finding is consistent with a study by Sharma and Kitchens (2004) who reported that teacher acts as a guide for students to know how to use the m-learning tools. In addition, technical staffs might also be helpful to guide the learners in using the m-learning system. As a matter of fact, one of the five critical success factors for m-learning project as proposed by Naismith and Corlett 
(as cited in Sharples et al., 2009) is the institutional support, which includes training staffs and technical supports.

Table 5. Preferences in interacting with learning supports

\begin{tabular}{lccccccc}
\hline & Items & \multicolumn{3}{c}{ Percentages of Agreement } & & \\
& 5 & 4 & 3 & 2 & 1 & Mean $^{\mathrm{a}}$ & SD \\
\hline System portal & 49.2 & 28.8 & 16.9 & 3.4 & 1.7 & 4.20 & 0.961 \\
Lecturer & 45.8 & 30.5 & 20.3 & 3.4 & 0 & 4.19 & 0.880 \\
Technical staffs & 37.3 & 35.6 & 22.0 & 5.1 & 0 & 4.05 & 0.899 \\
Course mates & 27.1 & 42.4 & 23.7 & 5.1 & 1.7 & 3.88 & 0.930 \\
Printed materials & 32.2 & 30.5 & 27.1 & 8.5 & 1.7 & 3.83 & 1.036 \\
SMS helpline system & 23.0 & 34.4 & 32.8 & 4.9 & 4.9 & 3.66 & 1.047 \\
a the means are determined by using a five-point Likert scale rating from strongly agree (5) to strongly disagree (1) &
\end{tabular}

Statistics described respondents' needs on portal, lecturer, technical staffs, course mates, printed materials and SMS helpline system as supports for SMS-based learning system

\section{Conclusions and Recommendations}

M-learning provides a viable platform for collaboration and interaction of students with their peers, instructors and learning system. The study reported here extends the understanding of effective interactivity of SMS-based m-learning from Malaysian perspective and thus have implications for the design of SMS-based m-learning system, specifically for the distance learners. Findings from this study demonstrated the distance learners' positive responses towards their needs on interaction with lecturer, course mates and the learning system. More specifically, the respondents were found to be keened towards interactive SMS-based m-learning applications that support them to ask query and receive the answers automatically, as well as to participate in quiz-like applications.

This research was a small-scale study, focused primarily on the perceptions of distance learners from one Malaysian university only. More researches are needed to investigate the types of SMS-based applications that can benefit students most through the interactivity gained from the m-learning environment. Even though this study managed to identify the importance of interactivity in SMS-based m-learning system for distance learners, future work that maps the system design to the learners' needs on interactivity in m-learning is yet to be explored.

It is undeniable that mobile technologies are applicable in promoting interactivity, as well as motivation for distance learners. Due to the fact that most distance learners have geographical and time limitations, mobility in learning would allow them to be in control of own learning process and have frequent contact with their instructors and peers. However, the question is, would SMS-based learning also be applicable for distance learners? Whether the answer is yes or not, m-learning via SMS still deserves consideration as one of effective ways in complementing current teaching and learning modes in universities. As the most common denominator of mobile technologies, the synergy between SMS-based learning tools and distance learners, therefore, holds enormous potentials.

\section{References}

Abas, Z. W., Chng, L. P., \& Mansor, N. (2009). A study on learner readiness for mobile learning at Open University Malaysia. Proceedings of IADIS International Conference Mobile Learning, 151-157.

Armatas, C., Holt, D., \& Rice, M. (2005). Balancing the possibilities for mobile technologies in higher education. Paper presented at the 22nd ASCILITE Conference, Brisbane, 4-7 December.

Brown, T. (2003). The role of m-learning in the future of e-learning in Africa? Retrieved January 12, 2012, from http://www.tml.tkk.fi/Opinnot/T-110.556/2004/Materiaali/brown03.pdf

Chinnery, G. M. (2006). Emerging technologies_-going to the MALL: Mobile Assisted Language Learning. Language Learning and Technology, 10(1), 9-16.

Corbeil, J. R., \& Valdes-Corbeil, M. E. (2007). Are you ready for mobile learning? Educause Quarterly, 30(2), 51-58. http://dx.doi.org/10.1522/24906497

Huang, Y.-M., Kuo, Y.-H., Lin, Y.-T., \& Cheng, S.-C. (2008). Toward interactive mobile synchronous learning 
environment with context-awareness service. Computers \& Education, 51(3), 1205-1226. http://dx.doi.org/10.1016/j.compedu.2007.11.009

Hui, G. L. S., \& Hock, G. T. (2005). Acceptance of SMS text information usage among college students. INTI Journal, 1(5), 487-499. http://dx.doi.org/10.1016/j.compedu.2007.11.009

Ismail, I., Gunasegaran, T., Koh, P. P., \& Idrus, R. M. (2010). Satisfaction of Distance Learners towards Mobile Learning in the Universiti Sains Malaysia. Malaysian Journal of Educational Technology, 10(2), 47-54. http://dx.doi.org/10.3991/ijim.v4i4.1408

J. C. Nunnally. (1978). Psychometric Theory (2nd ed.). McGraw-Hill, New York, 1978.

King, J. C., \& Doerfert, D. L. (2004). Interaction in the distance education setting. Retrieved December 20, 2011 from http://spot.pcc.edu/ rsuarez/rbs/school/EPFA_511/articles/from\%20Erica/interaction\%20in\%20de.pdf

Koole, M., McQuilkin, J. L., \& Ally, M. (2010). Mobile learning in distance education: Utility or futility? Journal of Distance Education, 24(2), 59-82.

Kumar, L. S., Jamatia, B., Aggarwal, A. K., \& Kannan, S. (2011). Mobile device intervention for student support services in distance education context - FRAME model perspective. European Journal of Open, Distance and E-Learning. Retrieved from http://www.eurodl.org/index.php? $\mathrm{p}=$ current\&article $=447$

Lim, T., Fadzil, M., \& Mansor, N. (2011). Mobile learning via SMS at Open University Malaysia: Equitable, effective and sustainable. International Review of Research in Open and Distance Learning, 12(2), 122-137.

Lin, Z., Jin, Y., \& Lin, H. (2008). The research of mobile support synergistic learning. Paper presented at the Web-based Learning, 2008. ICWL 2008. Seventh International Conference on. http://dx.doi.org/10.1109/ICWL.2008.14

Malaysian Communications and Multimedia Commission (MCMC) Report. (2008). Handphone users survey 2008. Retrieved January 16, 2012 from http://www.skmm.gov.my/link_file/facts_figures/stats/pdf/Handphone_Users_Survey_2008.pdf

Motiwalla, L. F. (2007). Mobile learning: A framework and evaluation. Computers \& Education, 49(3), 581-596. http://dx.doi.org/10.1016/j.compedu.2005.10.011

Motlik, S. (2008). Mobile learning in developing nations. International Review in Open and Distance learning, $9(2)$.

Moura, A., \& Carvalho, A. (2010). Mobile Learning: Using SMS in Educational Contexts Key Competencies in the Knowledge Society. In N. Reynolds, \& M. Turcsányi-Szabó (Eds.), (Vol. 324, pp. 281-291). Springer Boston. http://dx.doi.org/10.1007/978-3-642-15378-5_27

Naismith, L., \& Corlett, D. (2006). Reflections on success: A retrospective of the mLearn conference series 2002-2005. In Across generations and cultures, book of abstracts (pp. 118-120). Retrieved January 25, 2012, from http://telearn.noe-kaleidoscope.org/warehouse/Naismith-Corlett-2006 (001486v1).pdf

Ng, S. F., \& Confessore, G. J. (2011). Assessing the capacity for success in distance learning in Malaysia. Procedia - Social and Behavioral Sciences, 15(0), 1742-1750.

Ramli, A., Ismail, I., \& Idrus, R. M. (2010). Mobile learning via SMS among distance learners: does learning transfer occur? International Journal of Interactive Mobile Technologies, 4(3). http://dx.doi.org/10.3991/ijim.v4i3.1180

Randall, B., Seet, J., Lim, S., \& Elangovan, T. (2002). Blended learning using SMS. Retrieved 15 January, 2012, from http://www.learnerstogether.net/blended-learning-using-sms/51

Rosli, M., Ismail, I., Idrus, R. M., \& Ziden, A. A. (2010). Adoption of mobile learning among distance education students in Universiti Sains Malaysia. International Journal of Interactive Mobile Technologies, 4(2). http://dx.doi.org/10.3991/ijim.v4i2.1167

Safie, N. (2004). The use of Short Messaging System (SMS) as a supplementary learning tool in Open University Malaysia (OUM).18th Annual Conference Association of Asian Open Universities(AAOU), 27 November - 30 November, 2004, Shanghai, China, pp. 1-11.

Sharma, S. K., \& Kitchens, F. L. (2004). Web services architecture for m-learning. Electronic Journal of e-Learning, 2(1), 203-216.

Sharples, M., Arnedillo-Sánchez, I., Milrad, M., \& Vavoula, G. (2009). Mobile Learning Technology-Enhanced 
Learning. In N. Balacheff, S. Ludvigsen, T. Jong, A. Lazonder, \& S. Barnes (Eds.), Technology Enhanced Learning: Principles and Products (pp. 233-249). Springer Netherlands. http://dx.doi.org/10.1007/978-1-4020-9827-7_14

Shen, R., Wang, M., \& Pan, X. (2008). Increasing interactivity in blended classrooms through a cutting-edge mobile learning system. British Journal of Educational Technology, 39(6), 1073-1086. http://dx.doi.org/10.1111/j.1467-8535.2007.00778.x

Subramaniam, G. (2008). Confronting Asian concerns in engaging learners to online education. International Education Studies, 1(4), 10-18.

Wang, M., Shen, R., Novak, D., \& Pan, X. (2009). The impact of mobile learning on students' learning behaviours and performance: Report from a large blended classroom. British Journal of Educational Technology, 40(4), 673-695. http://dx.doi.org/10.1111/j.1467-8535.2008.00846.x

Yousuf, M. I. (2007). Effectiveness of mobile learning in distance education. Turkish Online Journal of Distance Education, 8(4), 114-124.

Yuen, M. C., Song, H. S. Y., \& Jong S. J. (2008). Digital habits of Malaysian students and its implication for learning: A preliminary study. In Smart Education: Converging technology, pedagogy and content. Proceedings International Malaysian Educational Technology Convention - IMETC2008, pp 221-227.

Zawacki-Richter, O., Brown, T., \& Delport, R. (2009). Mobile Learning: From Single Project Status into the Mainstream? European Journal of Open, Distance and E-Learning. Retrieved November 25, 2011 from www.eurodl.org

Zulkefly, S. N., \& Baharudin, R. (2009). Mobile phone use amongst students in a university in Malaysia: its correlates and relationship to psychological health. European Journal or Scientific Research, 37(2), 206-218. 